\title{
Strategi komunikasi politik dalam sosialisasi kebijakan masyarakat ekonomi ASEAN di Bandung Barat
}

\author{
Benazir Bona Pratamawaty ${ }^{1}$, Evie Ariadne Shinta Dewi², Putri Trulline ${ }^{3}$ \\ ${ }^{1,2,3}$ Universitas Padjadjaran, Bandung, Indonesia
}

\begin{abstract}
ABSTRAK
Sejak tahun 2016, Indonesia memasuki fase baru tatanan kehidupan bermasyarakat dalam lingkup kawasan ASEAN yakni dengan mulai efektifnya ASEAN Economic Community (AEC) atau yang lebih dikenal dengan Masyarakat Ekonomi ASEAN (MEA). Konsekuensinya, Indonesia harus membuka perdagangan barang, jasa, dan pasar tenaga kerja dengan negara ASEAN lainnya. Pemerintah, baik pusat maupun daerah, perlu menyosialisasikan kebijakan terkait MEA kepada seluruh stakeholders termasuk kepada masyarakat luas guna menyiapkan masyarakat menghadapi fase baru kehidupan perekonomian nasional akibat pemberlakuan MEA. Studi ini bertujuan untuk mengetahui model ideal strategi komunikasi politik bagi pemerintah daerah Kabupaten Bandung Barat dalam menyiapkan masyarakat menghadapi pemberlakuan MEA. Penelitian ini menggunakan pendekatan deskriptif kualitatif dengan metode studi kasus. Pengumpulan data dilakukan melalui kegiatan observasi, wawancara mendalam dan studi literatur. Pendekatan kualitatif dipandang relevan karena peneliti ingin mengkaji dan menganalisis secara mendalam strategi komunikasi politik pemerintah Kabupaten Bandung Barat dalam menyiapkan masyarakatnya menghadapi MEA. Hasil Penelitian menunjukkan bahwa model strategi komunikasi politik yang ideal bagi pemerintah Kabupaten Bandung Barat dalam mengkomunikasikan kebijakan terkait MEA harus dimulai dari komunikasi politik internal pemerintah Kabupaten Bandung Barat dalam rangka menyamakan persepsi dan menciptakan kesepahaman akan visi pemerintah terkait kebijakan-kebijakan MEA. Dengan demikian, komunikasi politik pemerintah kepada masyarakat pun dapat dilakukan secara lebih terarah dan terprogram melalui koordinasi dan kerjasama dinas-dinas dan badan-badan terkait pemerintah Kabupaten Bandung Barat.
\end{abstract}

Kata-kata Kunci: Strategi; komunikasi politik; sosialisasi; kebijakan; MEA; Bandung Barat

\section{Political Communication Strategy in Socializing ASEAN Economy Community Policies}

\section{ABSTRACT}

Since 2016, Indonesia has entered a new phase of social life structure within the scope of the ASEAN region, as the emerging of the ASEAN Economic Community (AEC) started. As a consequence, Indonesia must open trade in goods, services, and labor markets with other ASEAN countries. Both central and regional government needs to socialize policies related to the AEC to all stakeholders, including the broader community in order to prepare the public to face a new phase of national economic life due to the implementation of the AEC. This study aims to determine the ideal model of political communication strategy for the local government of West Bandung Regency in preparing the community for the implementation of the AEC. This research uses a qualitative descriptive approach with a case study method. Data collection was carried out through observation, in-depth interviews, and literature studies. The qualitative approach is seen as relevant because researchers want to study and analyze, in-depth, the political communication strategies of the West Bandung Regency government in preparing their communities to face the AEC. The results show that the ideal political communication strategy model for the West Bandung regency government in communicating policies related to the AEC should start from the internal political communication of the West Bandung regency government in order to synchronize perceptions and create an understanding of the government's vision regarding the AEC policies. Thus, the government's political communication to the public can be carried out smoothly through the coordination and cooperation of government agencies and related agencies.

Keywords: Strategy; communnication politics; socialization; policy; MEA; West Bandung

Korespondensi: Benazir Bona Pratamawaty, S.I.Kom., M.I.Kom. Universitas Padjadjaran, Jl. Raya BandungSumedang KM 21,Email: benazir.bona@unpad.ac.id 


\section{PENDAHULUAN}

Pemberlakuan Masyarakat Ekonomi ASEAN (MEA) dalam kawasan ASEAN telah berjalan selama kurang lebih tiga tahun namun gaungnya belum terdengar hingga daerahdaerah di Indonesia. Kabupaten Bandung Barat salah satu contohnya. Hasil observasi pra-studi yang dilakukan oleh peneliti menunjukkan belum adanya usaha pemerintah untuk mempublikasikan dan mengomunikasikan pemberlakuan MEA kepada masyarakat luas. Observasi pra-studi menunjukkan tidak ada sosialisasi kebijakan terkait pemberlakuan MEA dalam bentuk apapun oleh pemerintah daerah Kab. Bandung Barat - dalam bentuk publikasi dan penyebarluasan informasi menggunakan media, baik media konvensional maupun media digital. Website resmi pemerintah daerah Kabupaten Bandung Barat juga tidak memuat informasi terkait MEA (Catatan observasi, 2017).

Merujuk pada kebijakan Pemerintah Provinsi Jawa Barat tentang perlunya pemerintah daerah melakukan sosialisasi MEA, maka pemerintah daerah Kabupaten Bandung Barat yang merupakan salah satu dari 27 kota/ kabupaten di Jawa Barat, perlu mengeluarkan kebijakan komunikasi politik tertentu dalam rangka menyosialisasikan pemberlakuan MEA guna menyiapkan seluruh stakeholders terutama masyarakat awam dalam menghadapi fase baru tatanan perekonomian bangsa saat ini. Hal ini perlu dilakukan mengingat kebijakan internasional dalam tingkatan regional senantiasa berdampak langsung pada kehidupan sehari-hari masyarakat awam. Kehadiran MEA di tengah-tengah masyarakat harus diikuti dengan pemahaman dan perubahan cara berpikir masyarakat dalam menghadapi persaingan dunia usaha yang pada gilirannya menyentuh seluruh aspek kehidupan bermasyarakat.

Namun, berdasarkan pengamatan awal peneliti terhadap kebijakan komunikasi politikpemerintah daerah Kab. Bandung Barat, belum ada kebijakan khusus yang dibuat untuk mengomunikasikan kebijakan-kebijakan pemerintah terutama terkait mengantisipasi tantangan MEA kepada masyarakat luas, baik secara langsung maupun melalui media. Hal ini ditunjukkan dengan tidak adanya kegiatan atau kebijakan komunikasi politik yang dilakukan oleh Dinas Komunikasi dan
Informasi Kabupaten Bandung Barat dalam mengomunikasikan pemberlakuan MEA kepada masyarakat.

Per 1 Januari 2016, sepuluh negara anggota ASEAN telah memasuki fase baru kehidupan ekonomi dengan berlakunya kerjasama ekonomi kawasan bertajuk $A S E A N$ Economic Community (AEC) atau yang dikenal dengan Masyarakat Ekonomi ASEAN (MEA). Indonesia, Malaysia, Filipina, Singapura, Thailand, Brunei, Kamboja, Laos, Myanmar dan Vietnamtelah mempersiapkan dirinya dengan berupaya memenuhi AEC Blueprint 2007 dalam menyongsong era baru kebijakan ekonomi tingkat kawasan tersebut (AEC Secretariat, 2017). ASEAN memperkenalkan ASEAN Economic Community (AEC) Blueprint pada tahun 2007, yang merupakan inisiatif integrasi ekonomi kawasan paling ambisius di dunia selain Eropa (L. Jones \& Jones, 2016). Konsekuensi berlakunya MEA yang utama adalah Indonesia harus membuka perdagangan barang, jasa, dan pasar tenaga kerja dengan negara ASEAN lainnya.

Namun, pemberlakuan MEA tidak begitu disadari oleh masyarakat Indonesia. Hasil prariset menunjukkan bahwa masih banyak warga masyarakat yang awam dengan nama 'MEA'. Tidak hanya masyarakat umum, bahkan masih banyak pegawai pemerintah daerah yang belum akrab dengan nama 'MEA'. Selain itu, keberadaan MEA tidak pernah menjadi sorotan utama pemerintah. Hal ini ditunjukkan dengan minimnya informasi seputar MEA yang ditampilkan oleh media massa mainstream sejak awal 2016. MEA pun terasa jauh dan berjarak dari masyarakat. Padahal, salah satu semangat lahirnya MEA adalah menghasilkan kolaborasi ekonomi yang produktif diantara negara-negara anggota ASEAN. Tercapainya kolaborasi ekonomi membutuhkan peran aktif masyarakat sebagai pelaku utama ekonomi mikro.

Keadaan ini mengindikasikan seolaholah MEA hanyalah urusan pemerintah dan elite politik yang tidak memerlukan perlibatan masyarakat luas. Telah banyak hasil penelitian dalam bidang studi kawasan yang menyatakan bahwa proses terbentuknya komunitas ASEAN terlihat elit-sentris dan negara-sentris, ditunjukkan dengan minimnya usaha untuk mendengarkan aspirasi dari masyarakat pada umumnya terkait topik tersebut. Bahkan ada anggapan bahwa para pembuat kebijakan dan 
diplomat ASEAN bertindak terburu-buru dalam mendorong terbentuknya komunitas ASEAN sementara lebih dari 584 juta masyarakat negara-negara anggota ASEAN lupa akan semangat komunitas (Moorthy \& Benny, 2015). Bagaimanapun juga, komunitas ASEAN tidak memiliki komponen krusial yang mampu membawa kesuksesan bagi organisasi regional sejenis seperti European Union (EU), yakni keterlibatan langsung masyarakat luas atau berorientasi people-to-people. Tampak bahwa masyarakat negara anggota ASEAN belum memahami dan belum terlibat dalam proses membangun komunitas ASEAN. Isu utamanya adalah masyarakat di setiap negara anggota ASEAN memiliki persepsi, pendapat dan aspirasinya masing-masing tentang integrasi kawasan (Benny \& Abdullah, 2011).

Dengan demikian, memahami sentimen masyarakat terhadap sebuah kebijakan sangatlah penting. Dalam proses pembentukan sebuah integrasi kawasan, sangat penting untuk mengetahui pemahaman masyarakat tentang ide integrasi kawasan dan apakah masyarakat mendukung ide tersebut atau tidak. Bagaimanapun masyarakat adalah aktor utama sekaligus yang terkena dampak langsung dari proses regionalisasi tersebut (Benny \& Abdullah, 2011).

Studi yang dilakukan oleh Benny dan Abdullah (2011) tentang persepsi masyarakat Indonesia terhadap komunitas ASEAN menunjukkan bahwa proses pembentukan komunitas ASEAN belum melibatkan masyarakat luas dari negara-negara anggota. Tampaknya masyarakat Indonesia hanya memiliki sedikit pengetahuan mengenai ide pembentukan komunitas ASEAN. Masih banyak responden yang tidak mengetahui pembentukan komunitas ASEAN akan efektif pada tahun 2015 dan sebagian besar responden bahkan belum pernah mendengar ataupun membaca tentang komunitas ASEAN dan dokumen pendiriannya. Responden juga menyebutkan gagalnya komunikasi publik pemerintah dalam mempublikasikan dan menjelaskan kepada masyarakat luas perihal komunitas ASEANlah yang menyebabkan kurangnya pengetahuan masyarakat tentang isu tersebut (Benny \& Abdullah, 2011). Tidak optimalnya implementasi MEA di seluruh negara ASEAN mungkin merupakan akibat dari tidak kuatnya landasan lahirnya MEA, yang sebagian besar digagas karena adanya kepentingan politik alihalih kepentingan ekonomi (L. Jones \& Jones, 2016).

Kegagalan pemerintah mengomunikasikan dan mempublikasikan perihal komunitas ASEAN pun masih terasa hingga saat ini di masa pemberlakuan MEA. Pemberlakuan resmi Masyarakat Ekonomi ASEAN (MEA), sebagai bagian dari komunitas ASEAN pada 31 Desember 2015 menandai sejarah penting dalam agenda integrasi ekonomi ASEAN. Hal ini mengikuti implementasi pengukuran dari Blueprint MEA yang pertama (2008-2015), dengan pencapaian utama sebagai berikut: 1) pasar yang lebih terbuka, yakni dengan secara virtualmenghilangkantarifantarnegarakawasan dan secara bertahap menghapuskan batasanbatasan formal pada sektor jasa; 2) mengurangi biaya perdagangan dengan menyederhanakan prosedur perdagangan lintas batas, termasuk prosedur bea cukai dan aturan negara asal, harmonisasi regulasi teknis serta perjanjian atas kesepakatan bersama; 3) aturan investasi yang lebih menarik dan ramah terhadap bisnis serta inovasi lingkungan yang suportif melalui adaptasi kerangka kerja dan standar yang sama serta kerjasama saling menguntungkan pada berbagai bidang; dan 4) keterhubungan yang lebih baik dalam transportasi dan jaringan infrastruktur lainnya. Pada awal berdirinya, MEA mencakup sebuah pasar yang sangat besar dengan total GDP mencapai lebih dari US\$ 2,4 trilliun, yang menempatkan kawasan ini sebagai ekonomi terbesar keenam di dunia. ASEAN juga merupakan pasar ketiga terbesar di dunia, setelah Tiongkok dan India, dengan besar populasi sekitar 630 juta jiwa (ASEAN, 2017). Kekuatan ekonomi tersebut memberikan gambaran gamblang akan potensi MEA sebagai sebuah integrasi perekonomian kawasan yang mampu bersaing secara kompetitif di tingkatan global. Terbukanya pasar bebas bagi negaranegara ASEAN dengan mengalirnya barang, jasa, dan pekerja asing dalam lingkup kawasan tersebut, proyek MEA berniat dan berambisi untuk menjaga efisiensi basis pasar dan produksi tunggal yang meliputi hampir 600 juta penduduk dan produksi senilai 2 trilliun dolar AS (Petri, Plummer, \& Zhai, 2012).

Sebagai sebuah integrasi ekonomi kawasan, menarik melihat perbedaan yang sangat besar diantara negara anggota ASEAN dalam hal populasi, luas negara, dan pendapatan. Pertama, 
dalam hal populasi, anggota ASEAN dengan populasi terbesar adalah Indonesia dengan total populasi mencapai lebih dari 270 juta penduduk, sedangkan anggota dengan populasi terkecil adalah Brunei Darussalam dengan total populasi sekitar 500 ribu penduduk. Kedua, dalam hal luas area, Indonesia merupakan negara dengan luas area terbesar sedangkan negara dengan luas terkecil adalah Singapura. Ketiga, dalam hal pendapatan, karena besarnya jumlah penduduk, Indonesia juga merupakan negara dengan GDP tertinggi di ASEAN dan Laos merupakan negara dengan GDP terendah (Furuoka, Lim, Mahmud, \& Pazim, 2012).

Selain itu, meskipun negara anggota ASEAN berada dalam lingkup geografi yang sama dan berdekatan, setiap negara anggota ASEAN memiliki struktur dan bangunan ekonomi yang berbeda, demikian halnya juga orientasi politik, faktor-faktor pendukung, budaya, sejarah, dan agama yang berbeda (Valentina, Putera, \& Suherlan, 2016). Semua hal tersebut secara tidak langsung memengaruhi kebijakan pemerintah setiap negara dalam mengajukan proposal tarif impor kawasan yang pada gilirannya memengaruhi kebijakan dalam negeri dalam mengimplementasikan kebijakan luar negeri terkait MEA.

Sementara itu, dalam percaturan politik kawasan ASEAN, Indonesia dianggap memegang peranan yang sangat penting. Diantara 10 anggotan ASEAN, Indonesia merupakan negara dengan teritori, populasi, dan ekonomi terbesar. Mantan Sekretaris Jendral ASEAN Rodolfo Severino (2010) pernah menyebutkan empat alasan pentingnya peran Indonesia dalam perkembangan ASEAN. Pertama, Severino menyebutkan bahwa ASEAN baru bisa dibentuk setelah turunnya rezim Soekarno yang juga menandai berubahnya pendekatan kebijakan luar negeri Indonesia. Setelah rezim Soekarno, Jakarta setuju untuk bergabung dengan empat pendiri ASEAN lainnya - Malaysia, Filipina, Singapur, dan Thailand - untuk membentuk ASEAN pada tahun 1967. Kedua, dalam sejarah ASEAN, Indonesia memainkan peran sebagai pemimpin organisasi dan juga merupakan pelopor inisiatif pembentukan Komunitas Keamanan Politik ASEAN pada tahun 2003 dan juga bertindak sebagai pemimpin dalam perancangan Rencana Komunitas Keamanan ASEAN pada tahun 2004. Selain itu, peran dan kontribusi Indonesia terhadap organisasi ASEAN juga mencakup dimensi politik dan ekonomi. Severino juga menekankan bahwa upaya ASEAN dalam kerjasama dan integrasi ekonomi tidak akan tercapai jika Indonesia tidak membuka kebijakan ekonomi luar negerinya (Severino, 2010). Indonesia juga secara aktif mendorong peningkatan demokrasi dan hak asasi manusia dalam lingkup ASEAN. Salah satunya melalui keaktifan Indonesia mendorong terbentuknya lembaga perlindungan hak asasi manusia tingkat ASEAN dengan standar internasional yang pada akhirnya melahirkan ASEAN Intergovernmental Commission on Human Rights (AICHR) (Sukma, 2011).

Dengan kata lain, perkembangan integrasi kawasan dan ekonomi ASEAN sebagian besar dipengaruhi oleh keberadaan dan kontribusi Indonesia. Melihat pengaruhnya yang besar terhadap keberlangsungan organisasi tingkat kawasan ASEAN, Indonesia selayaknya memainkan peran kunci dalam perkembangan MEA, tidak hanya sebagai pembuat kebijakan tapi juga keterlibatan masyarakat industri. Oleh karenanya, pemerintah daerah sepatutnya ikut menyiapkan diri dalam menghadapi MEA, karena sebagai kebijakan internasional yang lahir dari perjanjian internasional, keberadaan MEA akan berdampak bagi kehidupan masyarakat negara anggota perjanjian tersebut. Mereka yang akan terkena dampak tidak hanya para pelaku usaha besar, namun juga pelaku usaha kecil, termasuk daerah-daerah yang baru lahir sebagai kota atau kabupaten hasil pemekaran seperti Kabupaten Bandung Barat (KBB). Pemerintah Kab. Bandung Barat sudah selayaknya mengantisipasi dampak ini, salah satunya dengan mengeluarkan kebijakan yang berlandaskan pada kebijakan pemerintah pusat terkait MEA. Idealnya, segera setelah kebijakan dibuat, maka pemerintah daerah perlu menyosialisasikannya kepada seluruh stakeholders termasuk kepada masyarakat luas guna menyiapkan masyarakat dalam menghadapi fase baru kehidupan perekonomian negara Indonesia di tingkat kawasan.

Indonesia, sebagai negara dengan pasar yang sangat besar, bahkan yang terbesar di ASEAN, sesungguhnya memiliki peluang yang juga sama besarnya dengan pasar yang ada. Langkah utama yang perlu diperhatikan oleh pemerintah adalah menyiapkan masyarakat menghadapi fase baru ini. Tidak hanya terfokus 
pada masyarakat pelaku usaha, melainkan pada masyarakat secara umum. Hal inilah yang harus diperhatikan oleh seluruh pemerintah daerah, termasuk pemerintah daerah Kab. Bandung Barat. Hal tersebut dapat dilakukan dengan membangun sebuah strategi komunikasi politik yang tepat dalam rangka menciptakan pemahaman dan perubahan cara berpikir masyarakat umum dalam menghadapi era pasar bebas di tingkat kawasan ASEAN ini. Strategi komunikasi politik yang tepat dapat menyiapkan masyarakat dengan pemahaman dan sikap kompetitif yang senantiasa waspada dalam menghadapi era baru MEA.

McNair mendefinisikan komunikasi politik sebagai sebuah kegiatan komunikasi mengenai politik yang disengaja dan didalamnya meliputi: semua bentuk komunikasi yang dilakukan oleh politisi dan aktor politik lainnya yang bertujuan untuk mencapai hasil tertentu; komunikasi yang ditujukan kepada aktor-aktor politik tersebut oleh non-politisi, seperti para pemilih dan kolumnis surat kabar; dan komunikasi tentang para aktor politik tersebut dan aktivitas mereka yang dimuat atau dipublikasikan dalam berita, editorial surat kabar, maupun bentuk diskusi politik lainnya yang menggunakan media. McNair juga berpendapat bahwa komunikasi politik tidak hanya meliputi bahasa verbal ataupun pernyataan tertulis, melainkan juga alatalat visual lainnya seperti pakaian, dandanan, gaya rambut, desain logo, yakni semua elemen komunikasi yang dapat dikatakan membentuk sebuah "citra" atau identitas politis (McNair, 2011).

Sementara itu, Perloff mendefinisikan komunikasi politik sebagai kegiatan komunikasi melalui bahasa dan simbol yang dilakukan oleh para politisi, pemerintah, media ataupun masyarakat yang memiliki efek tertentu (baik disengaja maupun tidak) terhadap pengetahuan, sikap, dan perilaku politik individu dan juga turut memengaruhi proses pembuatan kebijakan publik sebuah bangsa, negara, ataupun masyarakat (Perloff, 2015):

Particularly. that done by Karl Marx and Max Weber. In the 1930s, 1940s and 1950s, Marx's concepts of economic determinism and class struggle proved to be immensely popular, particularly in those parts of the world striving to overcome the ravages of war and the deprivations of colo-nialism. In the United States, however, preoccupied as it was to build a stable world order, it was Weber's thought that caught the attention of most social scientists. They were first attracted by Weber's concept of human history as a passage from tradition to modernity, earning for them the sobriquet of I"mod-emizationists. I" In the early postwar period, however, as the future of democracy seemed promising, most members of this school came to identify liberal democ-racy as the practical embodiment of modernity and focused their research on the process of democratization. Seymour Martin Lipset was particularly influential in setting the new agenda. In his seminal article, I"Some Social Requisites of Democracy: Economic Devel-opment and Political Legitimacy|” (1959).

Komunikasi politik pemerintahan, menurut Stephen Hess, adalah fungsi utama pemerintah dalam demokrasi, yaitu menyebarkan informasi tentang jalannya pemerintahan. Dasar pemikiran komunikasi pemerintah, adalah bahwa publik punya hak untuk tahu dan adanya kebutuhan pemerintah untuk memperoleh masukan dari publik. Secara umum, terdapat empat tujuan utama komunikasi pemerintah, yaitu memberitahu warga negara mengenai kebijakan pemerintah, DPRD, dinas-dinas, OPD, serta aktivitasnya sehari-hari; memberi kesempatan kepada warga menyatakan pandangannya mengenai proyekproyek yang penting/baru sebelum keputusan dijatuhkan oleh pejabat-pejabat yang dipilih; untuk memberikan penerangan kepada warga negara mengenai cara-cara kerja perangkat pemerintah dan memberikan informasi kepada mereka mengenai hak-hak dan kewajibannya; dan untuk meningkatkan rasa bangga sebagai warga negara. Sanders, dkk dalam studinya menyebutkan bahwa komunikasi pemerintah memainkan peran sentral dalam menyiapkan keputusan politik juga untuk memastikan jumlah suara mayoritas dalam parlemen (Sanders, Crespo, \& Holtz-Bacha, 2011).

Untuk mengetahui strategi komunikasi politik yang dilakukan oleh pemerintah Kab. Bandung Barat dalam menyosialisasikan MEA, peneliti menyelidiki dan menganalisis tiga komponen utama komunikasi politik, yakni organisasi politik, media, dan masyarakat sesuai dengan konteks penelitian. Dalam konteks 
penelitian ini peneliti mengkaji komunikasi politik yang dilakukan oleh pemerintah daerah sebagai organisasi politik; media dan strategi penggunaan media yang digunakan untuk menyampaikan pesan politik yang dimaksud; serta khalayak sasaran yang dituju oleh pemerintah daerah sebagai organisasi politik.

Tujuan penelitian adalah menyajikan rancangan model strategi komunikasi politik yang sesuai bagi pemerintah daerah Kabupaten Bandung Barat dalam menyosialisasikan kebijakan-kebijakan terkait MEA kepada masyarakat.

\section{METODE PENELITIAN}

Penelitian ini menggunakan pendekatan deskriptif kualitatif dengan metode studi kasus. Pendekatan kualitatif dipandang relevan dengan masalah yang diteliti dalam penelitian ini, dimana peneliti mengkaji dan menganalisis secara mendalam kesiapan serta strategi komunikasi politik pemerintah daerah Kabupaten Bandung Barat dalam menyiapkan masyarakatnya menghadapi MEA 2016.

Penelitian kualitatif merupakan metodemetode untuk mengeksplorasi dan memahami makna yang oleh sejumlah individu atau sekelompok orang dianggap berasal darimasalah sosial atau kemanusiaan. Proses penelitian kualitatif ini melibatkan upaya-upaya penting, seperti mengajukan pertanyaan-pertanyaan dan prosedur-prosedur, mengumpulkan data yang spesifik dari para partisipan, menganalisis data secara induktif mulai dari tema-tema yang khusus ke tema-tema umum, dan menafsirkan makna data. Laporan akhir untuk penelitian ini memiliki struktur atau kerangka yang fleksibel. Siapapun yang terlibat dalam bentuk penelitian ini harus menerapkan cara pandang penelitian yang bergaya induktif, berfokus terhadap makna individual, dan menerjemahkan kompleksitas suatu persoalan (Creswell, 2012).

Pendekatan kualitatif dilakukan untuk dapat memenuhi tujuan penelitian yakni ingin mengkaji dan menggali analisis yang mendalam mengenai strategikomunikasipolitik pemerintah daerah Kabupaten Bandung Barat dalam menyosialisasikan kebijakan-kebijakannya agar efektif diterima oleh masyarakatnya yang sedang menghadapi tantangan MEA.

Adapun metode penelitian yang digunakan dengan pendekatan kualitatif adalah metode studi kasus. Stake menyatakan bahwa studi kasus merupakan strategi penelitian dimana didalamnya peneliti menyelidiki secara cermat suatu program, peristiwa, aktivitas, proses, atau sekelompok individu. Kasus-kasus dibatasi oleh waktu dan aktivitas, dan peneliti mengumpulkan informasi secara lengkap dengan menggunakan berbagai prosedur pengumpulan data berdasarkan waktu yang telah ditentukan (Creswell, 2012).

Peneliti menggunakan metode studi kasus untuk menyelidiki secara cermat dan mendalam aktivitas yang dilakukan oleh pemerintah daerah Kabupaten Bandung Barat dalam menghadapi MEA dan strategi komunikasi politik dalam menyosialisasikan kebijakan-kebijakannya. Penggunaan metode studi kasus ini dengan landasan bahwasannya pemberlakuan MEA merupakan sebuah kegiatan dengan rentang waktu yang jelas dan merupakan sebuah program yang baru pertama kali diberlakukan dalam skala internasional di tingkat kawasan. Maka penting untuk mengkaji dan menganalisis kegiatan komunikasi politik yang dilakukan pemerintah dalam menghadapi era atau fase baru tatanan kehidupan bermasyarakat Indonesia saat ini. Hal ini dapat dimulai dengan mengkaji dan menganalisis aktivitas komunikasi politik yang terjadi di tingkat daerah, dalam hal ini pemerintah daerah Kab. Bandung Barat.

Data yang dibutuhkan dalam penelitian ini terbagi ke dalam dua jenis data, yakni data primer dan data sekunder. Data primer merupakan data yang didapatkan langsung dari subjek penelitian, yang dilakukan dengan melakukan wawancara mendalam terhadap subjek penelitian. Kegiatan wawancara mendalam yang dilakukan merupakan wawancara terstruktur dengan instrumen penelitian berupa daftar pertanyaan terstruktur yang telah disiapkan sebelumnya.

Data sekunder didapatkan dari sumbersumber lain yang relevan, seperti dokumendokumen yang berkaitan dengan kegiatan atau program komunikasi politik pemerintah daerah Kabupaten Bandung Barat dalam menghadapi MEA. Studi dokumentasi berupa peraturan daerah, surat perintah, surat keputusan dan artikel atau tulisan yang di media massa. Selain itu, data sekunder didapatkan melalui kegiatan observasi yang dilakukan secara langsung dalam setiap aktivitas atau program komunikasi politik yang dilakukan oleh pemerintah daerah Kab. Bandung Barat. 
Subjek penelitian ini adalah para pejabat pembuat keputusan di tingkat kabupaten yang memiliki peranan kuat dalam hal pembuatan kebijakan dan pembuatan keputusan sehubungan dengan berlakunya MEA, yang meliputi kepala daerah Kabupaten Bandung Barat (Bupati \& Wakil Bupati), Kepala Dinas Komunikasi dan Informasi beserta tim, dan Kepala Bagian Hubungan Masyarakat beserta tim, ketua DPRD serta pihak-pihak yang dianggap memiliki andil yang besar dalam pelaksanaan aktivitas komunikasi politik pemerintah daerah Kabupaten Bandung Barat sehubungan dengan pemberlakuan MEA 2016.

Sementara itu, objek penelitian ini adalah kegiatan atau program yang dilakukan oleh pemerintah daerah Kab. Bandung Barat dalam menghadapi MEA dan strategi komunikasi politik yang dilakukan guna menyosialisasikan berbagai kebijakan dalam rangka mempersiapkan masyarakat menghadapi MEA 2016.

Lazimnya penelitian deskriptif kualitatif, informan penelitian ditentukan dengan metode purposive sampling, yaitu memilih orang tertentu sebagai informan yang telah ditentukan terlebih dahulu kriterianya. Dalam penelitian ini, kriteria informan mencakup: Kepala Daerah atau wakilnya (Bupati /wakil bupati), Unsur legislatif (ketua atau anggota DPRD), Pejabat di lingkungan pemerintah daerah Kabupaten Bandung Barat yang setidaknya memiliki kewenangan untuk membuat kebijakan, baik kebijakan strategis maupun kebijakan teknis seperti kepala dinas sekretaris atau kepala bagian, tokoh masyarakat yang sering terlibat dalam proses pembuatan kebijakan pemerintah daerah Kab. Bandung Barat, dan tokoh media.

\section{HASIL DAN PEMBAHASAN}

Dari hasil pengumpulan data di lapangan berupa observasi dan beberapa wawancara mendalam dengan Dinas Komunikasi \& Informasi (Diskominfo) dan Dinas Perdagangan \& Perindustrian (Disperindag) Kabupaten Bandung Barat, diperoleh beberapa gambaran sebagai berikut:

Secara umum, baik Disperindag maupun Diskominfo menyatakan pemerintah daerah Kab. Bandung Barat belum memiliki strategi khusus untuk menghadapi MEA. Hal ini dikemukakan oleh PLT kepala Dinas
Perindustrian dan Perdagangan Avira, "Belum, belum ada kita sebatas Dinas kita aja, apa sih INDAG itu ke pelaku usaha apa aja sih yang harus mereka sampaikan, jadi kalau Masyarakat Ekonomi Asean ini mah sepintas gitu neng, belum secara khusus menggembleng dia menghadapi itu.. belum khusus, masih sepintas-sepintas aja".

Avira juga menambahkan bahwa karena belum memiliki strategi khusus untuk mengomunikasikan tentang MEA kepada para stakeholders, maka yang dilakukan hanya sebatas sosialisasi tentang bagaimana pelaku ekonomi sebaiknya mempersiapkan diri dalam menghadapi era MEA.

"Kemaren itu ada semacem sosialisasi pedagang ekspor impor, kemaren itu ada, memang ga secara langsung sih ya.. cuman ini aja eee.. sepintas gitu, sepintas untuk menyikapi biar dia lebih siap gitu loh ininya gitu.. ga harus dengan materinya langsung gitu, kemarin kita eee.. ada acara sosialisasi bulan Juli juga sih eh bulan Agustus kemaren di SPBU, kemaren kita ada".

Adapun yang menjadi khalayak sasaran kegiatan sosialisasi ini, menurut Avira, lebih diutamakan kepada para pengusaha kecil dan menengah berupa komoditas, walau ada juga pengusaha SPBU.

"Kita biasanya sosialisasi sih, kalau ada sosialisasi-sosialisasi di bidang perdagangan kita suka undang mereka kan pelaku usaha segala macem, SPBU segala macem kita udah sosialisasikanlah".

Ditambahkan Avira, peserta yang diundang adalah yang memiliki prospek bisnis bagus dan cukup menjanjikan di masa yang akan datang.

"Iya para pelaku usaha SPBU, terus kemaren eehhh eksport import, yang eksport import itu kan semua komoditi ya yang kita undang lah yang sekiranya prospeknya bagus yang arahnya, ya walupun dia belom eksport ya tetep aja kita dorong terus kita apa namanya kita bantulah ngasih pengetahuanpengetahuan yang lebih ini yang dia belum tau gitu dari segi kepemerintahan lah yaa. regulasi-regulasi pemerintah daerah, kalau usaha kan mereka lebih paham". 
Sosialisasi ini dilakukan untuk memberi bekal kepada para pelaku usaha agar meningkatkan kualitas produknya. Peningkatan kualitas produk sendiri menurut Avira dilakukan oleh pemerintah Kab. Bandung Barat salah satunya dengan membuat inovasi-inovasi produk yang khas menjadi identitas Kab. Bandung Barat, seperti batik oncom dan wajit Cililin, kendati belum sampai diekspor, tetapi pemasaran lokal sudah mulai tinggi.

"semua produk dan inovasi selalu kami himbau agar didaftarkan HKI dan SNI nya, karena yang memiliki nilai jual tinggi harus produk yang sudah berSNI".

Di luar negara ASEAN, Kab. Bandung Barat ternyata sudah menyasar pasar Timur Tengah, dengan mengeskpor cendera mata berupa miniatur binatang ke negara-negara di tanah Arab; ada pula industri agro yang mencakup makanan dan minuman berupa obat herbal berbahan dasar Jahe; Sementara itu pasar lokal meliputi: kerupuk gurilem, ikan pepetek, susu murni dan sayur mayur seperti wortel.

Selain untuk meningkatkan kualitas produk, para pelaku usaha juga diberi materi tentang pentingnya melengkapi berbagai dokumen perizinan,

"Yaa perizinannya apanya segala macem kita arahkan lah, kaya umpama kalau dia bergeraknya di industri makanan minuman itukan harus punya PIRT harus punya izinizin ya dari BPOM gitu, pelaku usaha kita kan gatau sampai kesana ya.. kalau yang izin-izin industri perdagangan.. yang gitugitu lah".

Dari wawancara dengan plt kepala Dinas Perindustrian dan Perdagangan ini nampak bahwa sosialisasi MEA belum dilakukan dengan menggunakan strategi khusus, mereka hanya fokus pada tugas pokok fungsi dinas yakni memfasilitasi dinas pertanian dan dinas koperasi \& UMKM untuk memasarkan produkproduk yang ada di masyarakat kepada para stakeholders.

"Ya kalau yang masalah itu sih udah mau eksport import tetep aja kita arahkan untuk melengkapi, minimal usahanya itu harus punya apa aja sih, minimal perizinanperizinan barangkali, perizinan lokallah yang ada didianya, kaya izin tetanggalah segala macem, kalau yang menyangkut makanan dan minuman berarti dia harus punya sertifikat PIRT yang dikeluarkan oleh Dinas Kesehatan, ya kita sifatnya mah mengantarkan aja kita dari Dinas sifatnya mengantarkan saja, karena kan perizinannya bukan kita yang ngeluarin ada perizinanya kan ada BPMPPT perizinan satu atap itu yang mengeluarkan, kalau kita cuman karna INDAG adanya dibawah binaan kita ya kita menghimbau aja".

Avira turut menambahkan, pengusaha kecil menengah di Kab. Bandung Barat nampaknya belum ada yang bisa menembus pasar eksport, salah satu kendalanya adalah persyaratan yang diinginkan untuk MEA itu belum bisa masuk, bahkan untuk standar supermarket tingkat nasional seperti BORMA saja masih sulit bagi para pelaku industri kecil dan menengah di Kabupaten Bandung Barat.

"kita jangan jauh-jauhlah kita ke pasaran yang lokal yang rada tinggi minimarketminimarket masuk ke Borma, kan kadangkadang ga bisa masuk, kemasannya juga itukan kalau di Borma kemasannya harus berdiri di kita biasanya masih duduk itu kan masih sangat kurang indah ya, kalau kemasannya $u d a h$ berdiri kan display-nya lebih bagus ya arahan-arahan yang gitugitu aja kalau dari INDAG mah".

Padahal, menurut Avira, pemerintah daerah sudah banyak memberikan kemudahan bagi para pengusaha kecil menengah ini, misalnya dalam hal pengurusan perizinan yang sudah dibuat satu atap agar lebih efisien dan efektif.

"Perizinan tidak ribet lagi kita sudah ada pelayanan satu atap, selama persyaratan udah lengkap bisa cepetlah itunya, tapi kadang-kadang mereka ga paham, banyak juga mereka belum paham, tapi kalau mereka yang sudah sering kita bawa pameran, udah sering kita pertemukan dengan istilahnya bapak angkat, kita pertemukan dengan pihak bank, kita juga kan ada kegiatan neng mempertemukan dengan pihak bank. Jadi para pelaku usaha itu bisa kredit di bank dengan mengagunkan tanda daftar industrinya, tanda daftar perdagangannya".

Berdasarkan hasil observasi dan wawancara yang telah peneliti lakukan, kami menemukan 
bahwa pada dasarnya MEA belum menjadi salah satu isu utama dalam program kerja pemerintah daerah Kabupaten Bandung Barat. Meskipun, banyak bagian dari jajaran pemerintah daerah mengakui mengetahui tentang MEA namun mereka belum memiliki pengetahuan dan pemahaman menyeluruh tentang pelaksanaan kebijakan MEA itu sendiri. Hal ini terlihat dari cara jajaran pemerintah daerah yang masih gamang dalam menjawab pertanyaan peneliti tentang bagaimana upaya Pemerintah daerah dalam menyosialisasikan program MEA. Semua jawaban yang diberikan lebih merujuk pada bagaimana dinas ataupun bidang kerja mereka melaksanakan kegiatan dan teknis di lapangan sesuai dengan tugas pokok dan fungsi dinas dan bidang masing-masing yang tidak dalam konteks MEA, padahal yang kami tanyai adalah setingkat kepala dinas.

Selain itu, Pemerintah daerah Kab. Bandung Barat melalui Dinas Perindustrian dan Perdagangan berdalih bahwa kewenangan daerah, dalam hal ini kabupaten, hanya membina Industri Kecil dan Menengah (IKM) yang nilai usahanya dibawah 10 milyar rupiah yang tidak mungkin melakukan ekspor. Oleh karenanya, mereka merasa bahwa MEA bukanlah sesuatu yang urgen untuk harus segera disikapi dengan program tertentu. Mereka juga merasa bahwa MEA adalah sesuatu yang belum relevan dengan masyarakat mereka, khususnya para pelaku IKM, oleh karenanya mereka merasa tidak perlu secara khusus mengomunikasikan MEA kepada para pelaku IKM.

Dengan demikian, jelas bahwa Pemerintah daerah Kabupaten Bandung Barat tidak memiliki strategi komunikasi politik khusus yang disiapkan untuk menyosialisasikan kebijakan di era MEA. Setiap SKPD maupun bidang kerja Pemerintah daerah Kab. Bandung melakukan pekerjaan sesuai dengan tugas pokok dan fungsinya masing-masing sesuai dengan program kerja yang telah dirancang sebelumnya. Poin tentang MEA atau topik terkait MEA hanya pernah disebutkan secara sekilas dalam kegiatan-kegiatan sosialisasi yang pernah mereka lakukan kepada masyarakat, tanpa adanya rancangan pesan maupun strategi komunikasi tertentu.

Hal tersebut telah dikonfirmasi oleh beberapa dinas terkait dalam lingkungan Pemerintah daerah Kabupaten Bandung Barat, yakni Dinas Komunikasi dan Informasi,
Dinas Tenaga Kerja dan Transmigrasi, Dinas Perindustrian dan Perdagangan, dan Bagian Perekonomian Sekretaris Daerah Kab. Bandung Barat. Padahal, dalam hal jumlah tenaga kerja, Indonesia merupakan negara anggota ASEAN dengan jumlah tenaga kerja terbanyak (Furuoka et al., 2012). Jumlah tenaga kerja yang besar ini tentu merupakan keuntungan bagi Indonesia dengan dibukanya pasar bebas dalam lingkup ASEAN.

Data hasil penelitian menunjukkan ketiadaan strategi komunikasi politik yang secara khusus disiapkan oleh Pemerintah daerah Kab. Bandung Barat untuk menyosialisasikan kebijakannya pada era MEA. Namun demikian, beberapa pihak yang telah kami wawancarai setuju bahwa pemerintah daerah memang membutuhkan strategi komunikasi politik khusus untuk menyosialisasikan kebijakankebijakan di era MEA saat ini.

Hasil penelitian juga menunjukkan bahwa fungsi komunikasi dan informasi dalam internal pemerintah daerah Kabupaten Bandung Barat yang tidak berjalan dengan baik merupakan penyebab utama terhambatnya diseminasi informasi terkait kebijakankebijakan pada era MEA, khususnya dalam lingkup pemerintah daerah itu sendiri. Hal ini kemudian menyebabkan tidak berjalannya fungsi komunikasi dan diseminasi informasi terkait kebijakan-kebijakan pada era MEA kepada masyarakat luas. Masyarakat kesulitan mendapatkan informasi yang utuh dan valid terkait kebijakan-kebijakan pada era MEA karena tidak terpusatnya informasi tersebut dari pemerintah. Selain itu, diseminasi informasi kebijakan-kebijakan pada era MEA yang tidak optimal dalam lingkup pemerintah daerah menyebabkan tidak meratanya pengetahuan dan pemahaman aparatur pemerintah daerah terkait kebijakan-kebijakan pada era MEA. Pada akhirnya menyebabkan informasi yang tersebar dan beredar di masyarakat pun simpang siur. Dari hasil kegiatan Pengabdian Pada Masyarakat (PPM) yang tim peneliti lakukan juga merupakan bagian dari rangkaian penelitian ini terhadap para pelaku Industri Kecil dan Menengah (IKM) di Kabupaten Bandung Barat ditemukan fakta bahwa masih banyak pelaku IKM yang kebingungan untuk mencari informasi terkait kebijakan pada era MEA. Beberapa pelaku IKM bahkan mengaku tengah berusaha memasuki pasar ASEAN dan 


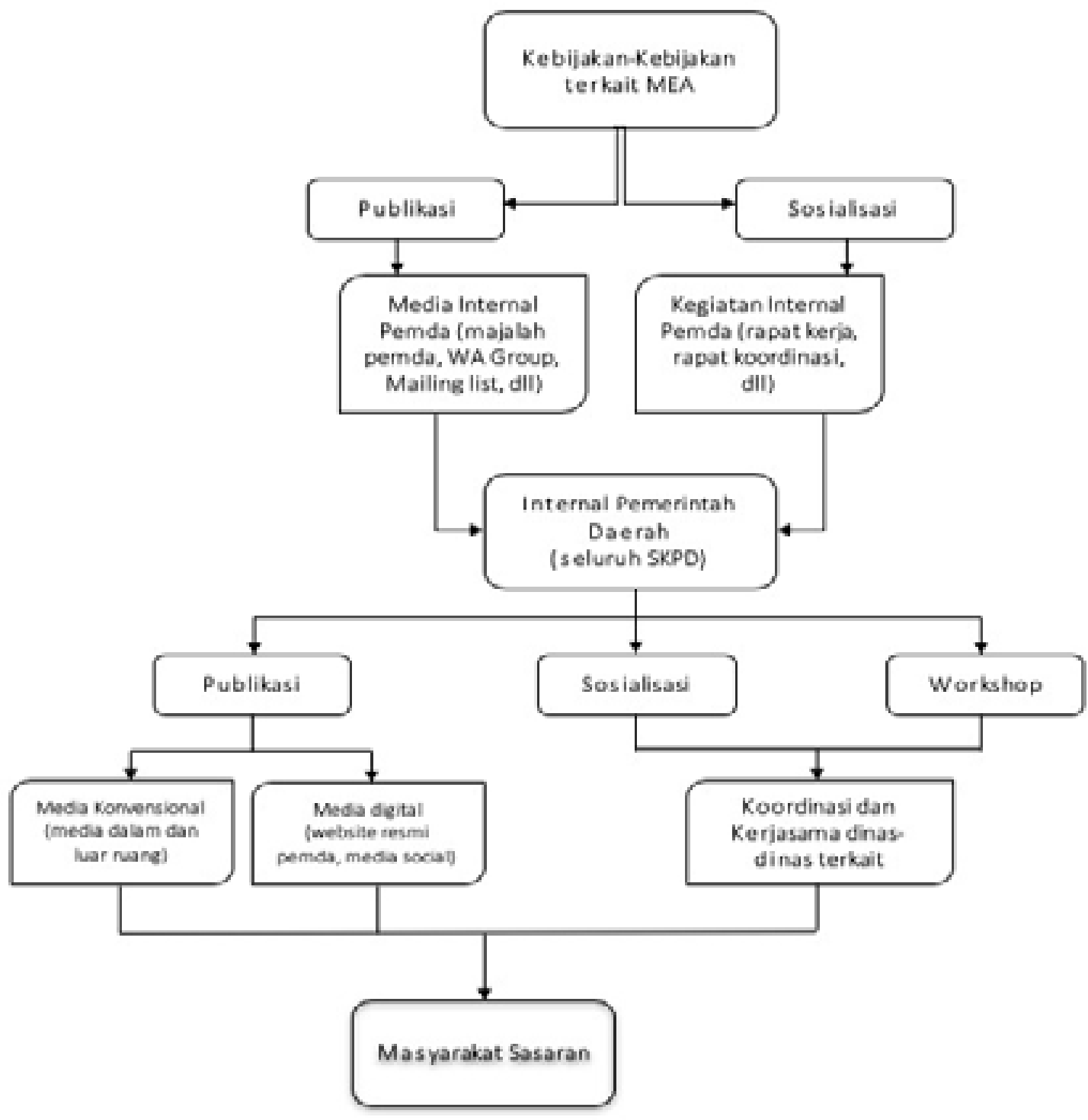

Sumber: Data olahan peneliti, 2018

Gambar 1 Model Strategi Komunikasi Politik Pemerintah Daerah Kab. Bandung Barat dalam Mengkomunikasikan Kebijakan-Kebijakan pada Era MEA

ASIA, namun berbenturan dengan peraturan dan kebijakan yang ada karena minimnya informasi yang dimilikinya terkait implementasi kebijakan MEA di lapangan, baik di tingkat nasional maupun regional Kawasan ASEAN dan Asia.

Hal ini sungguh disayangkan, mengingat besarnya potensi pelaku IKM di Kab. Bandung Barat untuk dapat memasuki pasar kawasan ASEAN. Dengan demikian, pemerintah daerah memerlukan sebuah model komunikasi politik yang ideal sesuai dengan kondisi dan situasi pemerintah daerah dan masyarakatnya saat ini dalam mengomunikasikan kebijakan-kebijakan pada era MEA. Adapun berdasarkan hasil analisis yang telah tim peneliti lakukan terhadap seluruh data hasil penelitian yang berhasil dikumpulkan, berikut adalah rancangan model komunikasi politik bagi pemerintah daerah Kabupaten Bandung Barat yang kami anggap ideal dalam mengomunikasikan kebijakankebijakan pada era MEA:

Pada model strategi komunikasi politik yang tersaji dalam gambar 1, kami menekankan pada komunikasi kebijakan-kebijakan terkait MEA pada lingkup internal pemerintah daerah terlebih dahulu. Hal ini karena salah satu hambatan utama komunikasi politik pemerintah daerah Kab. Bandung Barat terkait kebijakan MEA kepada masyarakat adalah belum optimalnya komunikasi dan koordinasi di dalam lingkungan pemerintah daerah itu sendiri. Hal ini sejalan dengan banyaknya kritik yang diberikan kepada komunitas ASEAN bahwa komunitas ini lebih banyak berorientasi elit atau hanya melibatkan kaum elit pemerintah negara 
tersebut saja. Studi lain juga menyebutkan bahwa komunitas ASEAN tidak memiliki sentuhan orientasi people-to-people atau mengenyampingkan pentingnya melibatkan masyarakat luas dalam prosesnya (Benny \& Abdullah, 2011). Kondisi yang terjadi dalam pemerintah daerah Kabupaten Bandung Barat adalah kebijakan terkait MEA hanya beredar terbatas pada kalangan manajemen atas pada tataran pemerintah daerah Kab. Bandung Barat. Komunikasi dan sosialisasi kepada jajaran dibawahnya tidak dilakukan secara optimal.

Selain itu, guna tercapainya tujuan akhir pemerintah daerah sebagai sebuah organisasi, maka penting untuk menyamakan dan menyatukan visi dan persepsi setiap komponen dan elemen pemerintah daerah. Hal ini seperti yang disampaikan oleh M. Rizky Safari, Kasubdit Jasa Ekonomi Dit. Kerja sama Ekonomi ASEAN berikut:

"Makanya, perlu pemahaman terhadap visi. Bukan hanya pemahaman visi, tetapi kesamaan visi di elemen masyarakat. Setiap anggota organisasi ini harus tahu target dan tujuan sasarannya apa. Output yang hasilkan tidak dan bukan berdasarkan orang-orang di organisasi, tetapi masyarakat keseluruhan, people oriented. Harus berfokus pada kemaslahatan umat. Jadi sisi internal organisasi harus ada pemahaman yang sama, outputnya harus menyangkut dampak positif terhadap masyarakat, misalnya peningkatan jumlah wirausaha, ok, yang menjadi wirausaha terdaftar semakin banyak dari 10.000 jadi 15.000, tapi ekonomi gak meningkat juga, berarti ada suatu hal yang salah. Jadi bukan melulu masalah kuantitas, tetapi kualitas itu tadi. Harusnya seiring peningkatan jumlah wirausaha di Kab. Bandung Barat, ekonominya juga harus meningkat".

Dengan demikian, langkah utama yang harus dan selayaknya dilakukan oleh pemerintah daerah adalah mengomunikasikan dan menyosialisasikan kebijakan-kebijakan terkait MEA dalam lingkungan internal pemerintah daerah, kepada seluruh SKPD dibawah kepemimpinan kepala daerah berkuasa.

Kegiatan tersebut dapat dilakukan menggunakan dua metode, yakni publikasi melalui media internal pemerintah daerah, baik konvensional maupun digital, dan sosialisasi melalui semua kegiatan internal pemerintah daerah. Kedua metode tersebut tentu saja harus dilakukan secara berkesinambungan dengan timeline yang jelas agar sesuai target pemerintah daerah. Dengan kegiatan komunikasi politik internal pemerintah daerah ini diharapkan dapat tercapai persamaan persepsi dan kesepahaman visi dalam kaitannya dengan MEA, agar setiap unsur dan elemen dalam pemerintah daerah dapat menafsirkannya dalam bentuk programprogram kerja yang sejalan dengan tujuan akhir pemerintah daerah. Selain itu, komunikasi politik internal pemerintah daerah ini juga untuk memastikan meratanya diseminasi informasi kebijakan-kebijakan terkait MEA kepada seluruh jajaran pemerintah daerah. Hal ini guna menghasilkan informasi yang akurat, tepat, dan jelas yang akan disampaikan kepada masyarakat.

Setelah komunikasi politik internal pemerintah daerah berjalan dengan baik dan ideal, maka langkah selanjutnya adalah mendiseminasikan informasi tersebut kepada masyarakat luas dan masyarakat sasaran, contohnya para pelaku IKM. Hasil studi sebelumnya menunjukkan bahwa hanya $42 \%$ responden Indonesia yang mengklaim pernah mendengar atau membaca tentang ide komunitas ASEN. Studi ini juga mengklaim bahwa ketidaktahuan masyarakat tentang komunitas ASEAN sebagiannya dikarenakan kegagalan pemerintah meneruskan informasi tersebut kepada masyarakat luas (Benny \& Abdullah, 2011).

Dengan demikian, kegiatan komunikasi politik kepada masyarakat membutuhkan strategi tertentu yang berkesinambungan dan berkelanjutan, tidak berjalan masing-masing. Dalam model strategi komunikasi politik yang kami bangun diatas, pemerintah daerah dapat menjangkau seluruh komponen masyarakat melalui metode publikasi, sosialisasi, dan workshop. Adapun metode publikasi dapat dilakukan menggunakan dua media, yakni media konvensional dan media digital. Media konvensional yang digunakan adalah media dalam dan luar ruang, seperti standing banner dalam kantor-kantor pelayanan masyarakat, spanduk dalam lingkungan pemerintahan daerah, juga memasang baliho pada jalan-jalan protokol yang sering dilalui oleh masyarakat sasaran. Media digital melalui optimalisasi website resmi dan akun resmi media sosial 
pemerintah daerah. Metode publikasi ini bertujuan untuk menumbuhkan kesadaran dan menambah pengetahuan masyarakat Kabupaten Bandung Barat tentang MEA, apa itu MEA, dan apa saja keuntungan dan tantangan yang dihadapi dengan berlakunya MEA.

Metode berikutnya adalah sosialisasi dan workshop. Kedua metode tersebut dapat diterapkan terhadap masyarakat sasaran khusus yang langsung terkena dampak pemberlakuan MEA, contohnya para pencari kerja dan para pelaku IKM Kabupaten Bandung Barat. Kegiatan sosialisasi dan workshop ini pun sebaiknya dilakukan oleh dinas-dinas terkait melalui koordinasi dan kerjasama dengan dinas-dinas dan badan pemerintahan lainnya dalam lingkungan pemerintah daerah. Hal ini guna mengoptimalkan kegiatan komunikasi politik pemerintah daerah kepada masyarakat. Setiap unsur dan elemen pemerintah daerah harus berkoordinasi dan bekerja sama dalam mengomunikasikan kebijakan-kebijakan MEA, guna menjamin keseragaman dan kevaliditasan informasi yang didiseminasikan kepada masyarakat terkait kebijakan-kebijakan MEA.

Meskipun masalah utama pemerintah daerah Kab. Bandung Barat sebelumnya adalah ketiadaan komunikasi dan koordinasi antarSKPD dalam pemerintahan, namun menurut pengakuan Ria Anjani dan Asep Koswara, sejak pergantian pemimpin yang baru, yakni Bupati dan Wakil Bupati terpilih periode tahun 2018-2023, perlahan-lahan setiap SKPD mulai membuka diri untuk mau berkoordinasi dan berkomunikasi dengan SKPD lainnya tanpa perlu melalui jalur hubungan interpersonal. Meskipun pemerintahan dibawah kepimpinan yang baru berjalan memasuki bulan ketiga, namun perubahan dalam komunikasi organisasi pemerintah daerah mulai terasa. Menurut pengakuan Ria dan Asep, atmosfer dan semangat baru yang dibawa oleh pemimpin baru memberikan pengaruh yang besar kepada seluruh jajaran pemerintah daerah dalam menjalankan tugas pokok dan fungsinya.

\section{SIMPULAN}

Penelitian ini menunjukkan bahwa strategi komunikasi politik pemerintah harus dimulai dari melakukan komunikasi politik pada tataran internal organisasi pemerintah guna tercapainya komunikasi politik yang efektif kepada masyarakat luas. Mengoptimalkan komunikasi politik internal organisasi pemerintah dapat menjamin keselarasan dan internalisasi visi dan misi pemerintah dalam setiap program kerja yang pemerintah hasilkan.

Keselarasan visi dan misi program kerja diantara semua anggota organisasi pemerintahan menjamin efektivitas penyampaian informasi dan kegiatan komunikasi politik pemerintah kepada masyarakat luas. Penelitian ini berhasil membuktikan kebenaran temuan penelitianpenelitian terdahulu bahwa komunitas ASEAN masih sangat elis-sentris dan berorientasi hanya pada lingkungan elit politik pemerintah.

Model yang dihasilkan dalam penelitian ini bersifat khusus karena berdasarkan pada kondisi dan situasi pemerintahan Kabupaten Bandung Barat serta kondisi masyarakat setempat. Kevalidan model yang kami hasilkan perlu diuji dalam penelitian selanjutnya menggunakan metode kuantitatif dengan mengimplementasikan metode tersebut dalam lingkup Kabupaten Bandung Barat. Selanjutnya, penelitian berikutnya dapat juga dilakukan dengan mengimplementasikan model pada dua atau tiga kota/kabupaten yang berbeda dengan karakteristik demografi masyarakat yang serupa dengan Kabupaten Bandung Barat. Penelitian bisa dilanjutkan dengan melakukan studi komparasi hasil implementasi model pada beberapa lokasi yang berbeda.

\section{DAFTAR PUSTAKA}

AEC Secretariat. (2017). Factsheet on ASEAN economic community. Retrieve from https://asean.org/?static_post=fact-sheetasean-economic-community-aec.

ASEAN. (2017). Towards ASEAN Economic Community 2025: monitoring asean economic integration. Retrieve from https:// asean.org/storage/2012/05/Towards-AEC2025-Monitoring-ASEAN-EconomicIntegration.pdf.

Benny, G. \& Abdullah, K. (2011). Indonesian perceptions and attitudes toward the ASEAN community. Journal of Current Southeast Asian Affairs. 30(1). 39-67. Retrieve from https://journals.sub.uni-hamburg.de/giga/ jsaa/article/view/410/408.html.

Creswell, J. W. (2012). Research design: pendekatan kualitatif, kuantitatif, dan mixed. Yogyakarta: Pustaka Pelajar. 
Furuoka, F., Lim, B., Mahmud, R., \& Pazim, K. H. (2012). Making pf The ASEAN Community: Economic Integration and Its Impact on Workers in Southeast Asia. Researchers World, 3(1), 68-74.

Jones, L., \& Jones, L. (2016). Explaining the failure of the ASEAN economic community : the primacy of domestic political economy explaining the failure of the ASEAN economic community: the primacy of domestic political economy. 2748. https:// doi.org/10.1080/09512748.2015.1022593

McNair, B. (2011). An Introduction to political communication, 5th Edition. London: Routledge.

Moorthy, R., \& Benny, G. (2015). Is an "ASEAN community" achievable? a public perception analysis in Indonesia, Malaysia, and Singapore on the Perceived Obstacles to Regional Community. Asian Survey, 52(6), 1043-1066.

Perloff, R. M. (2015). The dynamics of political change. Driven by Growth: Political Change in the Asia-Pacific Region. https://doi.org/10.1111/j.1467-9248.1969. tb00744.x.

Petri, P. A., Plummer, M. G., \& Zhai, F. (2012). ASEAN economic community: A general equilibrium analysis. Asian Economic Journal. 26(2), 93-118. https://doi. org/10.1111/j.1467-8381.2012.02079.x.

Sanders, K., Crespo, M. J. C., \& HoltzBacha, C. (2011). Communicating governments: a three-country comparison of how governments communicate with citizens. International Journal of Press/ Politics, 16(4), 523-547. https://doi. org/10.1177/1940161211418225.

Severino, R. C. (2010). ASEAN Community in Figures. Singapore.

Sukma, R. (2011). Indonesia Finds a New Voice. Journal of Democracy.

Valentina, T. R., Putera, R. E., \& Suherlan. (2016). ASEAN Economy Community (AEC) Indonesian politic of trade in contending with the simple market based production. Researchers World, 7(1), 8287. 